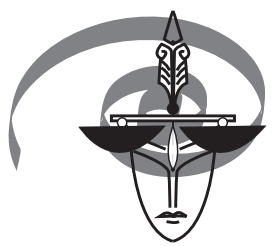

DOI: 10.2478/ep-2018-0007

Tuvya T. Amsel* Tel Aviv

\title{
Does the Law Circumvent Justice from Being Served?**
}

Обходит ли закон справедливость, когда это полезно?

Key words: evidence, justice, courts' objective, polygraph examination as evidence

Law - a binding custom or practice of a community: a rule of conduct or action prescribed [...] or formally recognized as binding [...] enforced by a controlling authority [...]. The courts exist to uphold, interpret, and apply the law [1].

Justice - the legal system that a country uses in order to deal with people who break the law $[\ldots]$ the administration of law according to prescribed and accepted principles [2]. In accordance with these definitions the Courts' objective (judges, jurors or tribunals) is to determine whether or not the defendant who stands for trial has committed the offense $s /$ he is accused of. In order to render their decision, courts practically travel back in time and re-construct and re-vive the occurrence surrounding the offense in order to establish the defendant where about and actions. In other words in order to serve justice the court has to be fully aware of the case facts i.e. the "factual truth" in order to be convinced "beyond any shadow of a doubt" that the defendant has committed the offense $s /$ he is accused of. To do so the courts summon witness who observed the

*ta@amsel.co.il

** "Reprinted from "W poszukiwaniu prawdy. Księga jubileuszowa ofiarowana Profesorowi Janowi Widackiemu” ( Search of the Truth - Tome for Jubilee of Professor Jan Widacki) Oficyna AFM, Kraków 2018”. 
incident along with forensic experts. Yet, no criminal justice system is perfect, which in return lead to miscarriages of justice. There are various reasons to wrongful convictions: eyewitness misidentification, mistaken forensic analysis, overly eager police investigators and prosecutors who falsify evidence and/or fail to disclose exculpatory evidence, inadequate legal representation, and many others.

Regardless of the inherited inaccuracy of those witnesses and experts by definition the legal system adopted laws that circumvent the courts of getting to the "factual truth" and by doing so the terms "judicial truth" or "legal truth" were coined. Just to mention a few: The fruits of the poisoned tree that regard as inadmissible, evidence that were obtained improperly, hearsay testimony that exclude testimony that was not sensed directly by the witness and alike. These limitations in spite of being sensible and just result many times in the acquittal of the guilty defendant which in return is a blow in the victims' faces and their families. These circumventing laws require the courts to overlook a confession of an assassin because he was not properly advised of his right although his confession was freely given without any coerce or to set a rapist free because of some technicality. With all due respect to the perpetrator rights what about the victims' rights? Is justice has been served or miscarriages of justice was practiced? Being so deeply concern with the perpetrator rights is appreciable but why should it be on the expense of the victims' rights? Didn't s/he suffer enough?

\section{The accuracy of admissible evidence}

If those circumventing laws are not damaging enough the courts' quest for justice, the admissible evidence themselves does not seem to be accurate enough to help the courts to expose the factual truth, for example:

- Eyewitness - inaccuracy was already established by Hugo Münsterberg in 1908 in his essays On the Witness Stand. Essays on Psychology and Crime [3]. Yale Law professor Edwin Borchard who studied 65 wrongful convictions for his pioneering 1932 book Convicting the Innocent [4], found that eyewitness misidentification was the leading contributing factor of wrongful convictions.

Since, similar findings were repeated again and again. According to the US National Registry of Exonerations out 2058 innocent people who were wrongfully convicted and who lost all together 17,895 years in jail $30 \%$ were wrongfully convicted because of eyewitness misidentification [5]. Project Innocent that exonerated 350 convicted people went even further by stating that: "Eyewitness misidentification is the greatest contributing factor to wrongful convictions proven by DNA testing, playing a role in more than $70 \%$ of convictions overturned through DNA testing nationwide" [6]; 
- Fingerprints - since 1995, there is an ongoing annual proficiency testing in the US for fingerprint experts. These are the results of the thousands of fingerprints experts who took the test: about 59\% of them made correct decisions, about $7,5 \%$ made an incorrect decisions, and about $34 \%$ were undecided [7];

- DNA - is practically about $75 \%$ accuracy because of: A chronic problem of uneven quality of forensic DNA laboratories, high rate of laboratory errors involving mix-up and cross-contamination of DNA samples, and finally DNA analysts who falsify test results in order to cover up for errors arising from cross-contamination of DNA samples and sample mix ups [8]. And if that is not bad enough, recently a Tel Aviv based life science company was able to create false DNA evidence that can point at any person that we want to incriminate [9];

- Hair - after it was established that in reality, there is no accepted research on how often hair from different people may appear the same, the FBI Crime Lab stopped using this method because it has "exceeded the limits of science" [10];

- Footprints - While Yoron Shor and Thomas Weisner found that footprint identification lacks a validated identification protocol [11] the US National Research Council concluded that footprint identification lack scientific basis and there is not enough accumulated data to reach a conclusion [12].

And the list of inaccurate admissible forensic evidence that was used for years and convicted innocent people goes on and on. According to the US National Registry of Exonerations out 2058 innocent people who were wrongfully convicted 23\% were wrongfully convicted because of false or misleading forensic evidence.

\section{Admissible evidence and courts' decision}

Unfortunately we do not know the exact numbers of wrongful convictions simply because the guilty suspects who were convicted claim innocence and the legal system is not very kin, to say the least, to expose the fact that the "king is naked". Yet, in order to get some idea of the figures beside those mentioned projects, one should read the alarming report of Andrew Gelman et al. who examined 4,578 appeals of death sentences in US states between 1973 and 1995 and found that the overall rate of prejudicial error in the American capital punishment system was 68\%. In other words, courts found serious, reversible error in nearly 7 of every 10 of the thousands of capital sentences that were fully reviewed during the period [...]. Capital trials produce so many mistakes that it takes three judicial inspections to catch them leaving grave doubt whether we do catch them all. After state courts threw out $47 \%$ of death sentences due to serious flaws, a later federal review found 'serious error' undermining the reliability of the outcome in $40 \%$ of the remaining sentences [13]. 


\section{Improving courts' decisions}

As alarming the inaccuracies of the admissible evidence are they should continue to be admitted in courts, in spite of their flaws. This is simply because each and every one of them, and especially as a whole, helps the courts to serve justice. The judge or juries are but human beings and in order for them to rule correctly they should have as much information as possible before rendering a decision.

In addition inadmissible evidence such as the polygraph test results and more should be entering the courts. Take the polygraph for example: in a laboratory study done by Jan Widacki and Frank Horvath eyewitnesses, fingerprints and handwriting analysis were compared to the polygraph results [14]. The study results demonstrated the superiority of the polygraph over the other evidence. A similar study conducted by Eitan Elaad produced similar results [15].

As practiced in medicine and psychiatry diagnosis, in were the prognosis is being done upon considering any possible analysis and tests available to the practitioner, courts should be exposed in the same manner to any possible existing evidence regardless of its' admissibility. Once having the whole picture, the courts will evaluate the evidence by its' weight rather than by its' admissibility and render they decision.

\section{References}

[1] Definition of law, see: www.merriam-webster.com/dictionary.

[2] Definition of justice, see: www.collinsdictionary.com/dictionary/english.

[3] Münsterberg H., 1908, On the Witness Stand. Essays on Psychology and Crime, Garden City (NY).

[4] Borchard E., 1932, Convicting the Innocent. Errors of Criminal Justice, Garden City (NY).

[5] US National Registry of Exonerations [website], www.law.umich.edu.

[6] Innocent Project / Eyewitness Misidentification, see: www.innocenceproject.org.

[7] Haber L., Haber R.N., 2004, Error Rates for Human Latent Fingerprint Examiners, [in:] Automatic Fingerprint Recognition Systems, eds N. Ratha, R. Bolle, New York, 339-360. 
[8] Thompson J.C., 2006, Tarnish on the "Gold Standard". Understanding Recent Problems in Forensic DNA Testing, "The Champion Magazine", January-February, $30,1,10-16$.

[9] Singer E., How DNA Evidence Can Be Falsified, 17.08.2009, see: www.technologyreview.com.

[10] Hsu S.S., Federal Review Stalled after Finding Forensic Errors by FBI Lab Unit Spanned Two Decades, 29.07.2014, see: www.washingtonpost.com.

[11] Shor Y., Weisner S., 1999, A Survey on the Conclusions Drawn on the Same Footwear Marks Obtained in Actual Cases by Several Experts Throughout the World, "Journal of Forensic Science", 44, 2, 380-384.

[12] Strengthening Forensic Science in United States. A Path Forward, 2009, National Research Council, The National Academies Press.

[13] Gelman A. et al., 2004, A Broken System. The Persistent Patterns of Reversals of Death Sentences in the United States, "Journal of Empirical Legal Studies", 1, 2, 209-261.

[14] Widacki J., Horvath F., 1978, Experimental Investigation of the Relative Validity and Utility of the Polygraph Technique and Three Other Common Methods of Criminal Investigation, "Journal of Forensic Sciences", 23, 3, 596-601.

[15] Elaad E., 2001, A Comparative Study of Polygraph Tests and Other Forensic Methods, Polygraph, 30, 1, 16-28. 